INDEPENDENT JOURNAL OF MANAGEMENT \& PRODUCTION (IJM\&P)

http://www.ijmp.jor.br

v. 11, n. 7, November - December 2020

ISSN: 2236-269X

DOI: 10.14807/ijmp.v11i7.1129

\title{
CUSTOMERS' PREFERENCES IN SELECTING ISLAMIC BANKS IN GULF COOPERATION COUNCIL (GCC) COUNTRIES
}

\author{
Abdelrhman Meero \\ College of Business Administration, Kingdom University, Bahrain \\ E-mail: ar.meero@ku.edu.bh \\ Nishad Nawaz \\ College of Business Administration, Kingdom University, Bahrain \\ E-mail:nishadnawaz@hotmail.com
}

Submission: 10/1/2019

Revision: $1 / 7 / 2020$

Accept: 1/30/2020

\section{ABSTRACT}

The present study aim to investigate relationship between religion, higher profitability on investment, sharia board audit, services (faster/friendly), bank reputation, product and service quality and to know which variable more influence in selecting Islamic banks in GCC countries. The study adopted convenience sampling. 101 completed questionnaires were chosen for analysis. The study found that there is no relationship in between consumer preferences and higher profitability on investment, services (faster/friendly), bank reputation, but there is, however, a significant relation with regards to religion, sharia board audit and product and service quality and paper provide fresh insights to the Islamic banks and recommendations, study implications, future research possibilities also discussed.

Keywords: Customers’ preferences, Islamic banks, GCC countries, sharia board audit, product and service quality. 
DOI: 10.14807/ijmp.v11i7.1129

\section{INTRODUCTION}

The core of Islamic banking profession is based on the sharia compliance and the prohibition of riba which is the interest based banking transactions (EROL; KAYNAK, 1990). Islamic banking is considered as a modern industry. The first professional appearance of Islamic banks was conducted in 1963 by Dr. Ahmad El Naggar in Mit-Ghamr, Egypt (OKUMUS; GUNEREN GENC, 2013). Despite this relative recent appearance of Islamic banking, it is initially considered as old as Islam itself which was appeared 1400 years ago.

During the last decades, the growth of Islamic finance has been accelerated and the Islamic finance assets have been grown from \$ 1.75 trillion in 2012 to \$ 2.44 trillion in 2017 and it is expected to reach $\$ 3.8$ trillion in 2023 (ISLAMIC FINANCIAL SERVICES BOARD, 2018) . Focusing more in GCC region, note that the market share of GCC Islamic banking is 42\% (ISLAMIC FINANCIAL SERVICES BOARD, 2017). GCC Islamic banks assets kept a moderate growth rate during 2017, Saudi Arabian Islamic banking assets grew at 2.7\%, Kuwaiti Islamic banks increased their assets by 3.6\%, the Islamic banks assets growth scored in Oman 15.6\% , 7.4\% in UAE, 6.9\% in Qatar.

Similarity of services offered by the banks increase the competition in the banking sector. This sharp competition motivate a research on the costumers decision of selecting a bank for their banking services (ALMOSSAWI, 2001; ZAINOL; SHAARI; ALI, 2009; ABDUH; KASSIM; DAHARI, 2012; ASCARZA et al., 2017). Looking for the criteria affecting bank selection shall help banks to design an appropriate marketing plan to attract new customers and to identify the suitable operational plan to maintain and satisfy the existing customers. Focusing in this study on the GCC region where more than $40 \%$ of Islamic assets are located shall give more importance to the results and it would increase also the credibility of the recommendations.

Therefore, we proposed a study of customers preferences in selecting Islamic banks in Gulf Cooperation Council (GCC) countries.

By having this background, the aim of the study is to bring out the relationship between religion, higher profitability on investment, sharia board audit, services (faster/friendly), bank reputation, product and service quality and which reason behind selecting Islamic banks by customers in GCC countries, in addition to know which of reason is more significant on customer preferences. 
DOI: 10.14807/ijmp.v11i7.1129

\section{LITERATURE REVIEW}

The purpose of this part is to draw our literature review with regards to existing customer preferences, religion, higher profitability on investment, sharia board audit, services (faster/friendly), bank reputation in Islamic banking system to be asked and discussed on the basis of our findings of the study and the existing literature until February 2019 is covered.

\subsection{Customer preferences}

In Banking selection process banking customers have different preferences. Several studies these preferences and tried to identify customer preferences for selecting their bank. From the old studies, (SIDDIQUE, 2012) found that the key factor affecting the customer's selection of a bank was the appropriate location, quality of the services and the length of bankcustomers relationships. (BOYD, 1994b) found that bank reputation and the interest on savings accounts are decisive criteria for Customers’ preferences in selecting banks in the USA.

lee and Ullah (2011) confirmed the previous result and gave more attention to the importance of Shari'a compliance in the selection of Islamic bank by the customers in Pakistan. (ECHCHABI; OLANIYI, 2012) found that the Islamic bank customers preference are meanly the service quality and the religious motivations in Malaysia. Similar results have been found by (BASHIR, 1999) in Kuwait, and (NASER JAMAL AL-KHATIB, 1999) in Jordan. The availability of various financial services and the high potential profitability are the most important indicators of selecting bank services in Pakistan (AWAN; BUKHARI, 2011). The literature review related to these different indicators shall be discussed in the following paragraphs.

\subsection{Religion}

The conventional banks operate under the regulation and the supervision of the national supervisory bodies. The Islamic banks is subject to the same regulations issued and imposed by the national supervisory body but in addition to that they should operate under the Islamic law or the Sharia. The Islamic banking system is based on the Sharia law as mentioned. The Islamic rules on all the transactions are called Fiqh al-Muamalat (MANSOUR et al., 2010).

The two fundamental principles of Islamic banking are the sharing of profit and loss and the prohibition of dealing with riba (SAQIB; FAROOQ; ZAFAR, 2016). Based on Islamic Sharia Islamic banks are not allowed to interfere or to invest in transactions involved alcohol, gambling, pork, and other forbidden items in GCC countries.(RAHMAN; BUKAIR; BUKAIR, 2013). 
DOI: 10.14807/ijmp.v11i7.1129

Delener, (1994) argued that the decision-making process of an individual is significantly affected by his religious believes. The results of the previous studies showed different degree of influence of the religious dimension on the bank selection. In 1989, (EROL; EL-BDOUR, 1989) found that the religious motives are not included in the list of the most important factors attracting customers to Islamic banks in Jordan. (HEGAZY, 1995) didn’t find the religious believes in the list of banks selecting criteria in Egypt.

Naser et al. (1999) found that the religious reasons are the second most important factor of selecting Islamic banks in Jordan. (AHMAD; HARON, 2000) found that the religious believes are not the only factor affecting the selection of the Islamic banks, but they are from the important criteria to be considered in the selection process.

Irwani (2007) pretend that using religious motives to attract Islamic banks costumers is no longer effective because customers are more interested in the quality and the availability of the bank services. Haque et al., (2009) found that the religion perspective is a major factor affecting the selection of Islamic banks. (AWAN; BUKHARI, 2011) found similar results in Pakistan where the customers give more value to the product features and to the quality of services. These two factors have been considered as more important than religious motives as major factors for making selection of Islamic banks.

Tameme and Asutay (2012) found that the religious motives have a significant effect on the decision of selecting the banking services provider. Okumus and Genc (2013) studied the bank selection and the client satisfaction of Turkish Banks. The results of the study showed that the religious motivation is the most important factor of bank selection criteria. Sori and Shah (2015) studied the effect of religion on the perception of service quality among Malay Muslims in Malaysia. The results of this study showed that the religious motive (Sharia compliance) is the first reason motivating Muslims for banking with Islamic banks.

Saqib et al. (2016) found that religious motivation is an important factor for Muslims in selecting their banks. In Tunisian banking sector, Souiden and Rani (2015) found that religious believe affects significantly the bank selection decision in Tunisia. Usman (2015) found a significant effect of religious motives on the selection of Islamic banks.

\subsection{Higher profitability on investment}

Looking for benefits and profits is a legitimate objective for banks customers and investors. The core of Islamic banking profession is based on the sharia compliance and articulated on two pillars: the first one is the prohibition of earning interest and the second is 
DOI: 10.14807/ijmp.v11i7.1129

the profit and loss sharing mechanism. Erol and Kaynak (1990) found that profitability is a key indicator for selecting banks in Jordan and this factor is more important than the religious beliefs. Naser et al. (1999) found that the Islamic banks profitability is the third important factor attracting customers after the confidentiality and the religious beliefs. Lee and Ullah (2011) pretended that Islamic banks customer might prefer these banks for their profitability.

Mansour et al. (2010) found that Islamic banks customer in UK prefer the low cost as the first selection criteria for their banks. In Pakistan, Awan and Bukhari (2011) found that high potential profitability is the second attractive motives for Islamic banks customers. For Islamic banks customer in Indonesia, the profitability is not a decisive criterion in the bank selection process Abduh et al. (2012). Same result has been found by Ascarza et al. (2017) in Turkey and by Hegazy (1995) in Egypt and by Zainol et al. (2009) in Malaysia as well. For Metawa; Almossawi (1998) Islamic banks customer is looking for the profitability as the second important factor of selecting banks after the religious motives.

\subsection{Sharia Board Audit}

The sharia board, or sometimes called Sharia Supervisory Board (SSB) is a crucial component of the Islamic banking governance system. SSB is usually situated near the top management level of the Islamic bank's governing structure. The sharia board has a broad latitude of responsibility which is meanly focused on the verification of the sharia compliance of the bank operations and the sharia compliance of the bank products and services.

Therefore, the Islamic banks are more audited and controlled than conventional banks where SSB is considered as sharia compliance auditor. Comparing to the conventional banks, Islamic banks are characterized by the existence of the Shariah supervisory board which the most important distinction between the two systems (FAROOK; HASSAN; LANIS, 2011). Rahman et al. (2013) that the existence of strong Shariah Board role shall strengthen the credibility of Islamic banks in front of their customers and investors. Does this role of Sharia Board affect the customer's bank selection decision.

Othman and Owen (2001) explained that the compliance of Islamic banking products with Sharia rules shall affect positively the quality of these products and services and leads to influence the costumer decision of bank selection. This conclusion has been confirmed also by (RAMDHANI; RAMDHANI; KURNIATI, 2011). As per the study of Rahman et al. (2013), the costumers and the investors prefer Islamic banks because their operations are in compliance with the Shariah rules and principles. Lee and Ullah (2011) and Okumus and Genc (2013) 
DOI: 10.14807/ijmp.v11i7.1129

explained that the important effect of the sharia compliance and SSB audit in the process of bank selection.

\subsection{Services (Faster/Friendly)}

The quality of the services offered by the Islamic banks is important determinant for the bank selection, but the quickness of offering the service is to be considered as decisive factor as well. Boyd (1994b) found that the quick services offered by the bank is a key factor for selecting the bank among the USA young customers. Haron, Ahmad and Planisek (1994) studied the preference of bank customers in Malaysia and they found that Islamic and conventional banks customers prefer banks that offer quick and efficient services.

Metawa and Almossawi (1998) found that Islamic banks in Bahrain should consider the quickness of the services offered to their customers to attract new customers and preserve the relationship with the current customers. Siddique (2012) studied the factors affecting the bank selection process in Rajshahi City. He found that the junior customers aged under 21 years prefer banks offering quick services. Mansour et al. (2010) pretend that customers of Islamic banks in UK give importance for the places where they have been served quickly and efficiently. Almossawi (2001) found that new generation prefer banks offering quick services and quick access to the services. Same result has been found by Ahmad, Rustam and Dent (2011) in International Islamic University of Malaysia.

\subsection{Bank reputation}

Firm reputation is an important factor which has been studied by several disciplines of social science like economics, marketing, strategy, finance and banking Fombrun and van Riel (1997). This factor provides a competitive advantage which attracts costumers and create more revenues Petticrew and Roberts (2006). In banking sector, previous studies found a positive impact of the bank reputation on the costumer decision of bank selection (EROL; KAYNAK, 1990). Boyd (1994a) found that young costumers aged under 21 are highly affected by the bank reputation when they make their bank selection decision.

Erol and Kaynak (1990) studied the determinant factors of selecting a bank in Jordan. The result of the study indicated the bank reputation and image as an important factor to be considered by bank customers in Jordan. The study has been done by Almossawi (2001) in Kingdom of Bahrain by having 1000 students aged between 19 and 24 years and found that bank reputation as the most important factor of the bank selection criteria. 
DOI: 10.14807/ijmp.v11i7.1129

For Erol and El-Bdour (1989) the quick and the efficiency of the service and the reputation of the bank have a significant effect on the bank selection decision. Gait and Worthington (2008) found that the Islamic bank reputation is a key factor of using Islamic banking products. Okumus and Genc (2013) found a significant effect of Islamic bank reputation in Turkish customer decision of bank selection.

\subsection{Product and service quality}

Product and service quality have been studied as part of the literature review related to the customer preferences of selecting banks. Cronin and Taylor (1992) describe the customer satisfaction as the logic results for the service quality offered in the banks. Haron et al. (1994) found service quality is decisive criterion for the selection process of Islamic and conventional banks customers in Malaysia. Stafford (1996) argue that competing in the banking sector is almost depend on the quality of the services offered. Levesque (1996) found that service quality is a very important factor to attract customer in retail banking.

Naser et al. (1999) found that service quality is a significant factor affecting the satisfaction of the Islamic banks customer in Jordan. Naser et al. (1999) found that the satisfaction of the customers depends significantly the quality of the services offered. Gait and Worthington (2008) identified the service quality as a key factor of selecting the Islamic banks. Hossain and Leo (2009) confirmed the effect of quality services on the customer satisfaction in the retail banking sector in Qatar.

Ahmad et al. (2011) found a positive significant relationship between the service quality and customer satisfaction in Islamic and non-Islamic retail bank in Pakistan. Ahmad et al. (2011) emphasized on the importance of the service quality for selecting the Islamic banks in Pakistan. Echchabi and Olaniyi (2012) pretend that the main factor affecting the Islamic bank selection in Malaysia is the service quality. Saqib et al. (2016) found that service quality is significantly related to the customer satisfaction in Islam banks in Pakistan. Same result has been found by Zameer et al. (2015) in Pakistan as well.

\section{RESEARCH METHODSS}

\subsection{Hypotheses development}

By considering the above empirical and theoretical arguments, here we have designed following hypothesis and tested and proposed research framework (Figure 1).

- $\mathrm{H} 1$ : There is a positive relationship between religious and customers preferences 
DOI: 10.14807/ijmp.v11i7.1129

- $\mathrm{H} 2$ : There is a positive relationship between higher profitability on investment and customers preferences

- H3 : There is a positive relationship between services (faster / friendly) and customers preferences

- H4 : There is a positive relationship between sharia board audit \& customers preferences

- $\quad \mathrm{H} 5$ :There is a positive relationship between bank reputation and customers preferences

- $\quad$ H6 :There is a positive relationship between product \& service quality and customers preferences

In the study, we examine relationship of religion, higher profitability on investment, sharia board audit, services (faster/friendly), bank reputation, product and service quality towards customer’s preferences in selecting Islamic banks in GCC countries.

Secondly, we would like to identify which variable is showing more significant towards selecting Islamic banks in GCC countries.

\subsection{Data collection and sample}

The present study collected data through well structure online questionnaire by help of google forms and the questionnaire has been divided by four sections part A was designed to collected personal data of the respondents (gender, nationality, age, marital status and occupation), part B was concentrated on selection of the bank, who influence to open account in the bank \& reasons behind to deposit their money at the Islamic bank. part C part includes product and service quality variables and the final part D questionnaire collects the information customer preferences.

There are total 21 variables were involved in the study to know the customer preferences, 5 variables related to the demographic information of the respondents, 3 variables for to know knowledge level of customers, in the total 9 variables were just designed get information regards to the product and services and remaining of the variables measured the customers preferences, Furthermore, in order to get adequate information, researchers approached personally contacted the respondents and collected their opinion in this regard.

The study adopted convenience sampling, and this is a technique widely used in qualitative research and the researchers made a plan to collect information from GCC countries 
DOI: 10.14807/ijmp.v11i7.1129

and some of them are not citizen of the GCC countries (expats). For the study we have considered religion, higher profitability on investment, sharia board audit, services (faster/friendly), bank reputation, product and service quality as a independent variable and customer's preferences as dependent variable.

The researchers circulated a questionnaire, by taking advantage of researchers' contacts, the questionnaire was disseminated, and the 120 respondents filled the questionnaire, while 101 respondents filled the questionnaire with-out any mistakes, these has been considered for the analysis. In addition, the researcher received the response from the following countries, Bahrain, Saudi Arabia, Kuwait, United Arab Emirates, Oman and Qatar and respondents list has been list in the Table 1. Table 1 shows that from Bahrain 18 respondents, Saudi Arabia 17 respondents, Oman 16 respondents, United Arab Emirates 17 respondents, Kuwait 18 respondents and Qatar 15 respondents are involved in the study.

Table 1: Participated countries list in the present study.

\begin{tabular}{ll}
\hline \multicolumn{2}{c}{ List of the countries participated in the study } \\
\hline & Responses (in Numbers) \\
Bahrain & 18 \\
Saudi Arabia & 17 \\
Oman & 16 \\
United Arab Emirates & 17 \\
Kuwait & 18 \\
Qatar & 15 \\
Total & 101 \\
\hline
\end{tabular}

\subsection{Measures}

The study adopted a five-point Likert scale was used (1 - strongly disagree to 5 strongly agree), in order to measure customer preference in selecting Islamic bank in GCC countries. Van alphen et al. (1994). The questionnaire items sources have been displayed in the Table 2.

Table 2: Conceptual framework of constructs

\begin{tabular}{|c|c|c|}
\hline No & Constructs & Variables References \\
\hline 1 & $\begin{array}{l}\text { Various reasons to select banks (religion, higher } \\
\text { profitability on investment, sharia board audit, } \\
\text { services (faster/friendly), bank reputation) }\end{array}$ & $\begin{array}{l}\text { (BASHIR, 1999; DELENER, 1994; AMIN; ISA, 2008; } \\
\text { AHMAD et al., 2011; HAQUE et al., 2009) }\end{array}$ \\
\hline 2 & Product and service quality & $\begin{array}{l}\text { (AHMAD; HARON, 2000; AWAN; } \text { BUKHARI, } \\
\text { 2011;PAUL; MITTAL; SRIVASTAV, 2016;AMIN; } \\
\text { ISA; FONTAINE, 2013) }\end{array}$ \\
\hline 3 & Customers satisfaction & $\begin{array}{l}\text { (AWAN; BUKHARI, 2011; } \\
\text { 1999;OKUMUS; GENC, 2013). }\end{array}$ \\
\hline
\end{tabular}

Source: Authors representation based on above mentioned references. 
ISSN: $2236-269 X$

DOI: 10.14807/ijmp.v11i7.1129

\subsection{Statistical Techniques Used}

The present study aimed to bring out the relationship between the customers preferences, reasons behind selecting Islamic bank and their level of satisfaction towards the Islamic banks. The data collected has been processed and analyzed by using descriptive statistics such as percentage, means, standard deviation, scales for reliability, $t$ test and regression. For getting of the result, we have used the statistical package for the social sciences, IBM SPSS, Version 25.

\section{RESULTS}

The study tested Cronbach alpha on the reasons behind dealing with Islamic bank, product and services, customers preferences, which produced that they are positive and significantly associated with each other. The reasons behind dealing with Islamic bank are with 5 items $(\alpha=0.82)$, product and services quality with 9 items $(\alpha=0.91)$ and customers preferences for selecting Islamic bank with 4 items $(\alpha=0.90)$ and this indicates that there is reliability of data and we have tested the descriptive statistics on collected data and in the first step of the analysis, we have analyzed the demographic profiles, selection of the banks, influence behind to open account and reasons behind handling with Islamic banking system. In the next step we tested the hypothesis and calculated which variable is influencing more on customer preferences on Islamic bank. Further, we have presented the results, after that discussed the results and finally paper terminated with study implications, limitations, and future research possibilities.

Table 3: Respondents information

\begin{tabular}{|c|c|c|c|c|c|}
\hline Variables & Frequency & Percentage & Variables & Frequency & Percentage \\
\hline Gender & & & Marital Status & & \\
\hline Male & 53 & 52.5 & Single & 37 & 36.6 \\
\hline Female & 48 & 47.5 & Married & 64 & 63.4 \\
\hline Nationality & & & Divorce & 00 & 00 \\
\hline GCC Citizen & 94 & 93.1 & Occupation & & \\
\hline $\begin{array}{l}\text { Non-GCC } \\
\text { Citizen }\end{array}$ & 7 & 6.9 & Government Sector & 28 & 27.7 \\
\hline Age & & & Private Sector & 42 & 41.6 \\
\hline Below 19 & 00 & 00 & Academic Staff & 3 & 3.0 \\
\hline $20-29$ & 44 & 43.6 & Students & 24 & 23.8 \\
\hline $30-39$ & 33 & 32.7 & Others & 4 & 4.0 \\
\hline $40-49$ & 20 & 19.8 & & & \\
\hline $50-59$ & 3 & 3.0 & & & \\
\hline 60 Above & 1 & 1.0 & & & \\
\hline
\end{tabular}

In the present study, the descriptive statistics displays that gender mean 1.48 and SD 0.50, and 52.50 percentage are male and 47.50 percentage are female. Regrading nationality 
DOI: 10.14807/ijmp.v11i7.1129

mean 1.08 and SD 0.25, 93.10 percentage are GCC citizens and rest of the respondents are Non-GCC citizens. About the age mean 2.85 and SD 0.91, 20-29 age between 43.60 percentage, 30-39 age 32.70 percentage, 40-49 age 19.80 percentage, 50-59 age 3 percentage and 60 above age 1 percentage.

Table 4: Customer selected bank

\begin{tabular}{lll}
\hline Variables & Frequency & Percentage \\
\hline Islamic bank & 67 & 66.3 \\
Conventional Bank & 16 & 15.8 \\
Both (Islamic bank \& Conventional Bank) & 18 & 17.8 \\
\hline Source: Data collected through questionnaire and own computation IBM SPSS, version 25.
\end{tabular}

Table 4 results indicated that 66.30 percentage of the respondents are using Islamic bank, 15.80 percentage of the respondents are using conventional bank and remaining of the respondents are using both bank. In addition, the values of the mean 1.51 and SD 0.78.

Table 5: who most influence to open account in the bank.

\begin{tabular}{lll}
\hline Variables & Frequency & Percentage \\
\hline Family & 19 & 18.8 \\
Relatives & 2 & 2.0 \\
Work Colleagues & 3 & 3.0 \\
Social Media & 3 & 3.0 \\
Self & 67 & 66.3 \\
Friends & 1 & 1.0 \\
Advertised by bank & 6 & 5.9
\end{tabular}

Source: Data collected through questionnaire and own computation IBM SPSS, version 25.

Table 5 shows that who is the person is influencing on them to open account in the banks, family members 18.80 percentage, relatives 2 percentage, work place colleagues 3 percentage, social media 3 percentage, self has 66.30 percentage, friends have 1 percentage and advertisements of the banks 5.90 percentage and descriptive statistics are as follows mean 4.36 and SD 1.87.

Table 6: Customers' reasons behind to deposit their money in Islamic bank

\begin{tabular}{lll}
\hline Variables & Frequency & Percentage \\
\hline Religious & 45 & 44.6 \\
Higher profitability on investment & 3 & 3.0 \\
Services (Faster/Friendly) & 11 & 10.9 \\
Sharia Board Audit & 32 & 31.7 \\
Bank reputation & 10 & 9.9 \\
Availability of branches (In different Locations / Timings) & 00 & 00 \\
\hline
\end{tabular}

Source: Data collected through questionnaire and own computation IBM SPSS, version 25.

In the matter of reasons behind selecting Islamic bank, the respondents are presented their views in different, 44.60 percentage agreed that religion is play important role, 3 percentage agreed that higher profitability on investment 3 percentage, services (faster/friendly) 10.90 percentage, sharia board audit has a 31.70 percentage and bank 
ISSN: 2236-269X

DOI: 10.14807/ijmp.v11i7.1129

reputation 9.90 percentage, these values we can observed from Table 6 and the mean and SD values as follows respectively, 2.59 and 1.54 .

Table 7 : Validation of research hypotheses

\begin{tabular}{|c|c|c|c|c|}
\hline Hypotheses & Relationships & $\mathrm{t}$ & $\mathrm{df}$ & Decision \\
\hline H1 & $\begin{array}{l}\text { There is a positive relationship between religious and customers } \\
\text { preferences }\end{array}$ & 1.90 & 68 & $*$ \\
\hline $\mathrm{H} 2$ & $\begin{array}{l}\text { There is a positive relationship between higher profitability on } \\
\text { investment and customers preferences }\end{array}$ & 0.83 & 46 & Not Significant \\
\hline H3 & $\begin{array}{l}\text { There is a positive relationship between services (faster / friendly) } \\
\text { and customers preferences }\end{array}$ & 0.75 & 53 & Not Significant \\
\hline H4 & $\begin{array}{l}\text { There is a positive relationship between sharia board audit \& } \\
\text { customers preferences }\end{array}$ & 1.71 & 54 & * \\
\hline H5 & $\begin{array}{l}\text { There is a positive relationship between } \\
\text { bank reputation and customers preferences }\end{array}$ & 0.57 & 50 & Not Significant \\
\hline H6 & $\begin{array}{l}\text { There is a positive relationship between } \\
\text { product \& service quality and customers preferences }\end{array}$ & 3.77 & 100 & $*$ \\
\hline
\end{tabular}

Source: Data collected through questionnaire and own computation IBM SPSS, version 25.

Note : * Indicates significant as indicated by one tailed t statistics $\mathrm{p}>0.05$ level df : degrees of freedom.

The study written the hypothesis on factors of influencing of customers to select Islamic bank, to bring out the first objective of the study, the relationship between religion, higher profitability on investment, sharia board audit, services (faster/friendly), bank reputation, product and service quality with customer's preferences in selecting Islamic banks in GCC countries, Therefore, we have examined this through $t$ test and results has been displayed in the Table 7. Which are not significant, that variables are not considered for further analysis and those have significant that only, we have considered for further analysis and discussion has been carried for that variables only (significant variables).

In the next step we have analyzed result, the results of that shown in the Table 7, as per the results there is no relation between higher profitability on investment, services (faster / friendly) and bank reputation with customers preferences in selecting Islamic bank, but there is a significant relation between the religion and sharia board audit with customers preferences in selected Islamic bank. On that basis we have designed the research framework it is shown in the Figure 1 and to know the second objective, which variable is more influencing on customers in selecting Islamic bank, we have tested the regression analysis to know that variables and the results has been shown in the Table 8 . 
DOI: 10.14807/ijmp.v11i7.1129

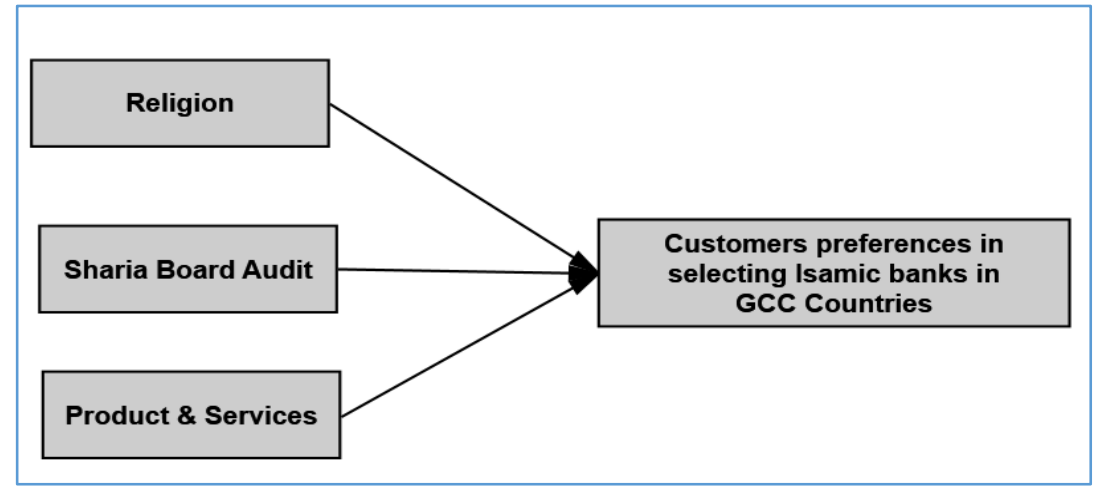

Figure 1: Research framework for the present study

Table 8 : Summary of coefficient / Standardized coefficient

\begin{tabular}{llll}
\hline Model & Beta & $\mathrm{t}$ & Significance \\
\hline Constant & & 4.67 & 0.001 \\
Religion & 0.305 & 1.79 & 0.012 \\
Sharia Board Audit & 0.216 & 1.61 & 0.004 \\
Product and services & 0.514 & 5.96 & 0.000 \\
& $\mathrm{~N}$ & & 110 \\
\hline
\end{tabular}

Source: Data collected through questionnaire and own computation IBM SPSS, version 25.

Table 8 results explaining values of standardized coefficient beta and presented all the values of coefficient independent variables (religion, sharia board audit, product and service quality) and dependent variables (customer's preferences), we have tested the regression analysis \& values are presented in Table 8 . For calculating comparison, we have considered the beta values, we can observed that beta values in the Table 8 , from the Table 8 we have calculated the highest score variable, after clear observation we found that product and services with beta value is 0.514 with "t" 5.96 , with compared to sharia board audit \& religion, at same way we have identified that religion had secured second place by having beta value 0.305 with "t" 1.79 and finally sharia board audit scored is beta 0.216 with "t" 1.61 and it is clearly that, which variable is more weightage in selecting Islamic banks in GCC countries.

\section{DISCUSSION}

The aim of study is to know the relationship between the religion, higher profitability on investment, sharia board audit, services (faster / friendly), bank reputation, product and service quality, how theses factors are playing role in selecting banks in GCC countries and adding to that, which variable is more weightage in the opinion of the customers to select banks in the region.

The research explained their demographic information male respondents are more than female, while compare single, married are involved in the study. In nationality category most them are citizen of GCC country and the rest of them are expats, in age area below 19 age are 
DOI: 10.14807/ijmp.v11i7.1129

zero, 20 and 29 age between 44 respondents, and 30 and 39 age between 33 respondents and rest of the people are fall under 40 and 49, 50 and 59 \& 60 above, in next area of the study, occupation those who are working in private sector are involved more than government and rest of them are students and others.

In the matter of customers selection of the bank most of the customers are showing much interest in Islamic bank and some of them are chosen the Conventional bank and rest of the people maintaining the both banks accounts for their money transactions. As same the findings of Lee and Ullah (2011) in Pakistan and Echchabi and Olaniyi (2012) in Malaysia. In another part of the study how is the influencer to open an account in the Bank, in that most of them self-motivated to open an account and second place goes to the family members influence to open account and rest of the items such as relatives, colleagues, social media, friends and advertisement by bank are not much influenced in account opening in the bank, likewise, the customers are depositing their money in Islamic banks on the basis of various reasons, the study found that religion is playing very important role. There are similar studies has been in Malaysia (AHMAD; HARON, 2000; IRWANI, 2007; RAMDHANI et al., 2011) in Indonesia. The faster / friendly services are in third and rest of the reasons are influencing in small number, another feature of the influencing factor, branches in different locations with different timings not showing any influence.

After that the study like to know the relationship between the religion, higher profitability on investment, sharia board audit, services (faster/friendly), bank reputation, product and service quality with customers preferences, therefore, we have tested the test, the results shown in the Table 7 and the hypothesis are placed to know the significant, in that $\mathrm{H} 2$, H3 \& H5 are not presented quite good values, which we can considered as significant, its implies that higher profitability on investment, services like faster and friendly, bank reputation are not shown any relationship.

However some of the studies found higher profitability on investment, services like faster \& friendly and bank reputation positive influences as per the location Ascarza et al. (2017), Zainol et al. (2009) and Saqib et al. (2016). The values of religious and sharia board audit are positive and shown good influent in selecting of Islamic banks in the region. In another factor of our study, the product \& service quality also shows much influence in selecting Islamic banks in GCC countries opted by customers. The sharia board audit influence more the customers, while selecting of the bank Tameme and Asutay (2012) and Mohamad et al. (2015). 
DOI: 10.14807/ijmp.v11i7.1129

The study found that there is good influence of product and service quality on customers preferences, in that product category has much influent towards Islamic banks, they are offering more benefits than Conventional banks, they are displays of products on the leaflet /brochures / website, this will all help customers to understand better about the products of the Islamic banks. Customers are very convinced on the products, features, benefits offering by the Islamic banks, therefore, they are very much attracted, and they do not have any doubts on Islamic banks products.

Moreover, the customers are very much happy about the operation time, services, frontdesk, e-banking and SMS services. Customers are satisfied with profit rate offered by the bank, getting prompt services at any time, assurance on shariah compliance products, terms and conditions set Islamic banks, all these all acceptable. Overall customers of Islamic banks are very happy in the region. Another work of Metawa and Almossawi (1998) in Bahrain, Bashir (1999) from Kuwait stated the same.

The study findings are suggested following recommendations for the Islamic banks in GCC countries.

Islamic banks have to have concentrate on to open new ATMs centers and branches in various locations and need to open branches in regionally \& internationally as well to avoid inconvenience of the customers.

Islamic banks required to increase their high profitability, this will be attract more customers and very helpful to enhance bank reputation in nationally, regionally \& internationally.

\section{CONCLUSION.}

The study implications for academic and practice, first, the paper offers a better understanding between the consumer preferences and religion, higher profitability on investment, sharia board audit, services (faster/friendly), bank reputation, product and service quality and relations to each other. More precisely, the paper offered points (i.e religion, sharia board audit \& product and service quality) to the organizations, by use of this, organizations can offer more research activities, on the other hand, might analyze their present situation.

In the part of any research, this study has limitations, the present study has his scope is limited to cover only selected Islamic banks in GCC countries of surveyed Islamic banks willing to participate in the study by covering reasons behind selecting Islamic bank, product and services and customers preferences. 
DOI: 10.14807/ijmp.v11i7.1129

The study can be extended by having large number of sample size in GCC countries, the finding would be more meaningful. It is opportunity to study individual country by having good number of sample size. The study can be done cross country and individual comparisons of banks, product and services comparison in order to know more similarities / differences / strengths \& weakness. It is possible to have more variables, same sample size and same countries the study can be done or else increasing sample size and adding variables also possible to have the same.

The results of the study show that the religion and the sharia board audit are the most important reasons behind the selection of Islamic banking services. The recent development in the financial technology sector and the forced liberalization of the financial services could create difficulties in verifying the effect of these factors in selecting the banking services. This would favorize an extension of the study to examine the effect of FinTech on the nature of Islamic banking services and the competitive advantages of Islamic banks.

\section{REFERENCES}

ABDUH, M.; KASSIM, S.; DAHARI, Z. (2012) Customer satisfaction and switching behavior in Islamic banking: evidence from Indonesia. School of Doctoral Studies (European Union) Journal, Table 1, p. 209-215. Retrieved from www.bi.go.id

AHMAD, K.; RUSTAM, G. A.; DENT, M. M. (2011) Brand preference in Islamic banking. Journal of Islamic Marketing, v. 2, n. 1, p. 74-82. DOI: 10.1108/17590831111115259

ALMOSSAWI, M. (2001) Bank selection criteria employed by college students in Bahrain: an empirical analysis. International Journal of Bank Marketing, v. 19, n. 3, p. 115-125. DOI: $10.1108 / 02652320110388540$

AMIN, M.; ISA, Z. (2008) An examination of the relationship between service quality perception and customer satisfaction: A SEM approach towards Malaysian Islamic banking. International Journal of Islamic and Middle Eastern Finance and Management, v. 1, n. 3, p. 191-209. DOI: 10.1108/17538390810901131

AMIN, M.; ISA, Z.; FONTAINE, R. (2013) Islamic banks: contrasting the drivers of customer satisfaction on image, trust, and loyalty of Muslim and non-Muslim customers in Malaysia. International Journal of Bank Marketing, v. 31, n. 2, p. 79-97. DOI: $10.1108 / 02652321311298627$

ASCARZA, E.; EBBES, P.; NETZER, O.; DANIELSON, M. (2017) Interest free banking in Turkey : a study of customer satisfaction and bank selection. Journal of Marketing Research, v. 54, n. 3, p. 347-363. DOI: 10.1509/jmr.15.0442

AWAN, H. M.; BUKHARI, K. S. (2011) Customer's criteria for selecting an Islamic bank: evidence from Pakistan. Journal of Islamic Marketing, v. 2, n. 1, p. 14-27. DOI: 10.1108/17590831111115213

BASHIR, A.-H. M. (1999) Risk and proftablity measures in Islamic banks : the case of two Sudanese banks. Islamic Economic Studies, v. 6. 
CRONIN, J. J.; TAYLOR, S. A. (1992) Measuring service quality: a reexamination and extension. Journal of Marketing, v. 56, n. 3, p. 55. DOI: 10.2307/1252296

DELENER, N. (1994) Religious contrasts in consumer decision behaviour patterns: their dimensions and marketing implications. European Journal of Marketing, v. 28, n. 5, p. 3653. DOI: 10.1108/03090569410062023

DUSUKI, A. W.; ABDULLAH, N. I. (2007) Maqasid al-Shari ah, Maslahah, and corporate social responsibility. The American Journal of Islamic Social Sciences, v. 24, n. 1, p. 2545. DOI: $10.1007 / 978-3-642-40535-8$

ECHCHABI, A.; OLANIYI, O. N. (2012) Malaysian consumers' preferences for Islamic banking attributes. International Journal of Social Economics, v. 39, n. 11, p. 859-874. DOI: 10.1108/03068291211263907

EROL, C.; KAYNAK, E. (1990) Conventional and Islamic banks: patronage behaviour of Jordanian customers. International Journal of Bank Marketing, v. 8, n. 4, p. 25-35. DOI: $10.1108 / 02652329010004231$

EROL, G.; EL-BDOUR, R. (1989) Attitudes, behaviour, and patronage factors of bank customers towards Islamic banks. International Journal of Bank Marketing, v. 7, n. 6, p. 31-37. DOI: doi:10.1108/02652328910132060

FAROOK, S.; KABIR HASSAN, M.; LANIS, R. (2011) Determinants of corporate social responsibility disclosure: the case of Islamic banks. Journal of Islamic Accounting and Business Research, v. 2, n. 2, p. 114-141. DOI: 10.1108/17590811111170539

FOMBRUN, C. J.; VAN RIEL, C. B. M. (1997) The reputational landscape. Corporate Reputation Review, v. 1, n. 1, p. 5-13. DOI: 10.1057/palgrave.crr.1540024

GAIT, A.; WORTHINGTON, A. (2008) An empirical survey of individual consumer, business firm and financial institution attitudes towards Islamic methods of finance. International Journal of Social Economics. DOI: 10.1108/03068290810905423

HAQUE, A.; OSMAN, J.; ZAKI, A.; ISMAIL, H. (2009) Factor influences selection of Islamic banking: a study on Malaysian customer preferences. American Journal of Applied Sciences, v. 6, n. 5, p. 922-928.

HARON, S.; AHMAD, N.; PLANISEK, S. L. (1994) Bank patronage factors of Muslim and Non-Muslim customers. International Journal of Bank Marketing, v. 12, n. 1, p. 32-40. DOI: $10.1108 / 02652329410049599$

HEGAZY, I. A. (1995) An empirical comparative study between Islamic and commercial banks selection criteria in Egypt. International Journal of Commerce and Management, v. 5, n. 3, p. 46-61. DOI: 10.1108/eb047313

HOSSAIN, M.; LEO, S. (2009) Customer perception on service quality in retail banking in Middle East: the case of Qatar. International Journal of Islamic and Middle Eastern Finance and Management, v. 2, n. 4, p. 338-350. DOI: 10.1108/17538390911006386

ISLAMIC FINANCIAL SERVICES BOARD. (2017) Islamic financial services industry. Islamic financial serIvices industry stability report 2017. Retrieved from http://www.ifsb.org

ISLAMIC FINANCIAL SERVICES BOARD. (2018) Islamic financial services industry stability report.

LEE, K. H.; ULLAH, S. (2011) Customers' attitude toward Islamic banking in Pakistan. International Journal of Islamic and Middle Eastern Finance and Management, v. 4, n. 2, p. 131-145. DOI: 10.1108/17538391111144524 
MANSOUR, W.; BEN ABDELHAMID, M.; MASOOD, O.; NIAZI, G. S. K. (2010) Islamic banking and customers' preferences : the case of the UK. Qualitative Research in Financial Markets, v. 2, n. 3, p. 185-199. DOI: 10.1108/17554171011091746

METAWA, S. A.; ALMOSSAWI, M. (1998) Banking behavior of Islamic bank customers : Perspectives and implications. International Journal of Bank Marketing, v. 16, n. 7, p. 299313. DOI: $10.1108 / 02652329810246028$

MOHAMAD, S.; SORI, Z. M.; SHAH, M. (2015) Shariah governance: effectiveness of shariah committees in Islamic banks in Malaysia. SSRN. DOI: 10.2139/ssrn.2555373

NASER, K.; JAMAL, A.; AL-KHATIB, K. (1999) Islamic banking: A study of customer satisfaction and preferences in Jordan. International Journal of Bank Marketing, v. 17, n. 3, p. 135-151. DOI: 10.1108/02652329910269275

AHMAD, N.; HARON, S. (2000) Perceptions of Malaysian corporate customers towards Islamic banking products \& services. International Journal of Islamic Financial Services, v. 3, n. 4, p. 1-16.

OKUMUS, H. S.; GENC, E. G. (2013) Interest free banking in Turkey : a study of customer statisfaction and bank selection. Euoropen Scientific Jounal, v. 9, n. 16, p. 1857-7881.

OTHMAN, A.; OWEN, L. (2001) The multi dimensionality of carter model to measure customer service quality (SQ) in Islamic banking industry: a study in Kuwait finance house. International Journal of Islamic Financial Services, v. 3, n. 4, p. 1-12.

PAUL, J.; MITTAL, A.; SRIVASTAV, G. (2016) Impact of service quality on customer satisfaction in private and public sector banks. International Journal of Bank Marketing, v. 34, n. 5, p. 606-622. DOI: 10.1108/IJBM-03-2015-0030

PETTICREW, M.; ROBERTS, H. (2006) Systematic Reviews in the Social Sciences: A Practical Guide. Blackwell. DOI: 10.1027/1016-9040.11.3.244

RAHMAN, A. A.; BUKAIR, A. A.; AWADH BUKAIR, A. (2013) The influence of the shariah supervision board on corporate social responsibility disclosure by Islamic Banks of Gulf CoOperation Council Countries. Asian Journal of Business and Accounting, v. 6, n. 2, p. 2013.

RAMDHANI, M. A.; RAMDHANI, A.; KURNIATI, D. M. (2011) The influence of service quality toward customer satisfaction of Islamic sharia bank. Australian Journal of Basic and Applied Sciences, v. 5, n. 9, p. 1099-1104. Retrieved from http://www.scopus.com/inward/record.url?eid=2-s2.081755188001\&partnerID=MN8TOARS

STAFFORD, M. R. (1996) Demographic discriminators of service quality in the banking industry. Journal of Services Marketing, v. 10, n. 4, p. 6-22. DOI: 10.1108/08876049610124554

SAQIB, L.; FAROOQ, M. A.; ZAFAR, A. M. (2016) Customer perception regarding Sharī‘ah compliance of Islamic banking sector of Pakistan. Journal of Islamic Accounting and Business Research, v. 7, n. 4, p. 282-303. DOI: 10.1108/JIABR-08-2013-0031

SIDDIQUE, M. N.-E.-A. (2012) Bank selection influencing factors : A study on customer preferences with reference to rajshahi city. Asian Business Review, v. 1, n. 1, p. 80-87. DOI: 10.18034/abr.v1i1.340

SOUIDEN, N.; RANI, M. (2015) Consumer attitudes and purchase intentions toward Islamic banks : the influence of religiosity. International Journal of Bank Marketing, v. 33, n. 2, p. 143-161. DOI: 10.1108/IJBM-10-2013-0115 
TAMEME, M.; ASUTAY, M. (2012) An empirical inquiry into marketing Islamic mortgages in the UK. International Journal of Bank Marketing, v. 30, n. 3, p. 150-167. DOI: $10.1108 / 02652321211222531$

LEVESQUE, G. H. G. M. T. (1996) Determinants of customer satisfaction in retail banking. Transportation Research Record, v. 14, n. 7, p. 12-20.

USMAN, H. (2015) The role of religious norms in selectionof Islamic banking. Al-Iqtishad, v. 7, n. 1, p. 31-44.

VAN ALPHEN, A.; HALFENS, R.; HASMAN, A.; IMBOS, T. (1994) Likert or Rasch? Nothing is more applicable than good theory. Journal of Advanced Nursing, v. 20, n. 1, p. 196-201. DOI: 10.1046/j.1365-2648.1994.20010196.x

BOYD, W. L.; LEONARD, M.; WHITE, C. (1994a) Customer preferences for financial services: an analysis. International Journal of Bank Marketing, v. 12, n. 1, p. 9-15.

ZAINOL, Z.; SHAARI, R.; ALI, H. M. (2009) A comparative analysis on bankers' perceptions on Islamic banking. International Journal of Business and Management, v. 3, n. 4, p. 157168. DOI: $10.5539 / \mathrm{ijbm} . v 3 n 4 p 157$

ZAMEER, H.; TARA, A.; KAUSAR, U.; MOHSIN, A. (2015) Impact of service quality, corporate image and customer satisfaction towards customers' perceived value in the banking sector in Pakistan. Marketing Intelligence and Planning, v. 33, n. 4, p. 442-456. DOI: 10.1108/IJBM-01-2014-0015. 